\title{
電動車椅子の各種操作方法による走行実験
}

\section{A Running Experiment on The Various Operation Methods of An Electric Wheelchair}

\author{
○正 浅川 貴史（神奈川工科大） \\ 正西原 主計（神奈川工科大） \\ 正 吉留 忠史（神奈川工科大）
}

Takashi ASAKAWA, Kanagawa-Institute of Technology, t-asa@asap-sys.co.jp
Tadashi YOSHIDOME, Kanagawa Institute of Technology
Kazue NISHIHARA, Kanagawa-Institute of Technology

This study conducted the running experiment on the various operation methods of the electric wheelchair. There are a joystick type, a push-button type, and a voice control type in the operation methods of an electric wheelchair. The joystick type used what is generally marketed, and the push-button type and the voice control type were made as an experiment newly. In the experiment, it ran the course using above-mentioned operation methods, and measured transit time and the turning counts.

Key Words: Wheelchair, Voice control

\section{1.はじめに}

現在, 電動車椅子の操作方法には, ジョイスティックを用 いたものが一般的であり，その他に重度肢体障がい者向けの 「前後左右」の押しボタンを使用するものや，研究段階では あるが音声制御を用いたものがある。これらの操作方法には、 操作になれるまでに時間がかかったり，細かな方向の操作が むずかしいなどの問題があるため，使用者や使用する場所な どの状況を考え，各操作力法の特徵を把握することが重要で ある。

特に音声認識を利用した制御力法は，いろいろな場面で活 用され始め，福祉の分野でも注目が集まっている。しかしな がら，これまでの操作方法をそのまま音声制御に置き換える ことは多くの問題を引き起こす可能性がある.

そこで本研究では，ジョイスティック式・押しボタン式・ 音声制御式の3つの方法について，同じ環境下で実際に走行 実験を行い，動作の完了度を測定した。

ジョイスティック式は，一般的に市販されているものを使 用した。押しボタン式は，ボタンを押している間だけ動作す るタイプと押しボタンを一度押すと動作を開始し，ストップ ボタンで停止するタイプの2 種類を試作した。また，音声制 御式は, 音声命令のみで動作するタイプと, 音声命令で動作 を開始し，ストップボタンで停止するタイプの2種類を試作 した．以上の3タイプ5種類の操作方法を用意し実験を行っ た。

\section{2. システムの構成}

\section{1 ジョイスティック式}

ジョイスティック式のシステムは，一般に市販されている ものを使用した。市販の電動車椅子には電動専用の車体を持 つものと，通常の手動式車椅子に電動ユニットを付加したも のがあるが，今回は後者タイプを使用した。

車椅子本体, 電動ユニットから構成される使用機材を表 1
に，車椅子の全体図を図 1 に示す.

Table 1 Used equipments of a joystick type

\begin{tabular}{|l|l|}
\hline \multicolumn{1}{|c|}{ Equipment } & \multicolumn{1}{c|}{ Maker and Model } \\
\hline \hline Wheelchair & Kawamura Cycle BM22-40 \\
\hline Electric power unit & Yamaha JW-1 \\
\hline
\end{tabular}

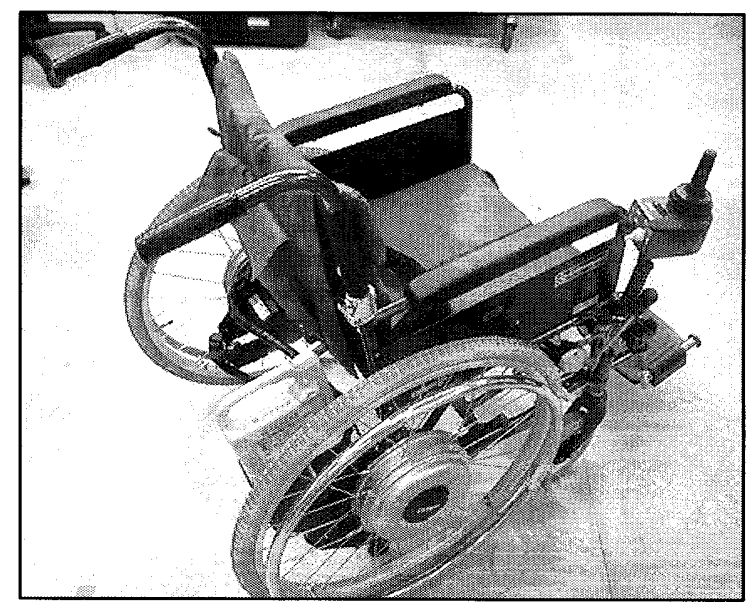

Fig.1 Electric Wheelchair

\section{2 押しボタン式}

押しボタン式のシステムは、ジョイスティック式電動車椅 子のジョイスティックコニット部分をマイコン制御ユニット に置き換え，更に図 2 の押しボタン操作パネルを追加したシ ステムで構成されている，図２のように押しボタンには前後 左右のそれぞれのボタンと停止ボタンがある。

操作方法には，ボタンを押している間だけ動作する「A モ ード」と，ボタンを押すと動作を開始しストップボタンで停 止する「Bモード」があり、マイコン制御ユニットにより制 
御している.

車椅子本体とジョイスティックコニット以外の電動ユニッ

トはジョイスティック式のものをそのまま流用している.

追加の使用機材を表 2 に、マイコン制御ユニットを図 3 に 示す.
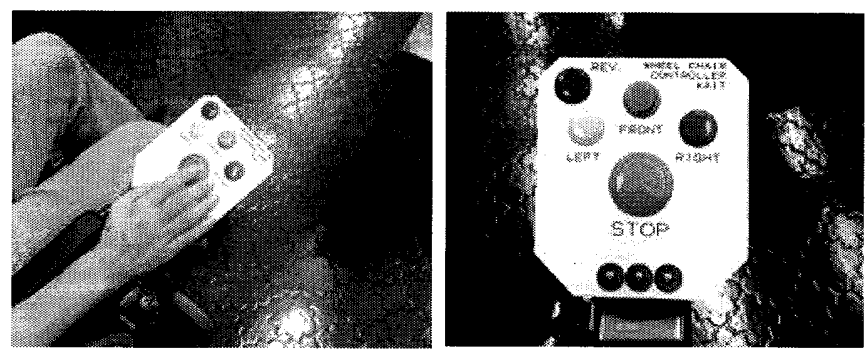

Fig.2 Push-button type

Table 2 Used equipments of a joystick type

\begin{tabular}{|l|l|}
\hline \multicolumn{1}{|c|}{ Equipment } & \multicolumn{1}{c|}{ Maker and Model } \\
\hline \hline Micro computer module & ASAP system \\
\hline Electric power unit & Yoneyama works \\
\hline
\end{tabular}

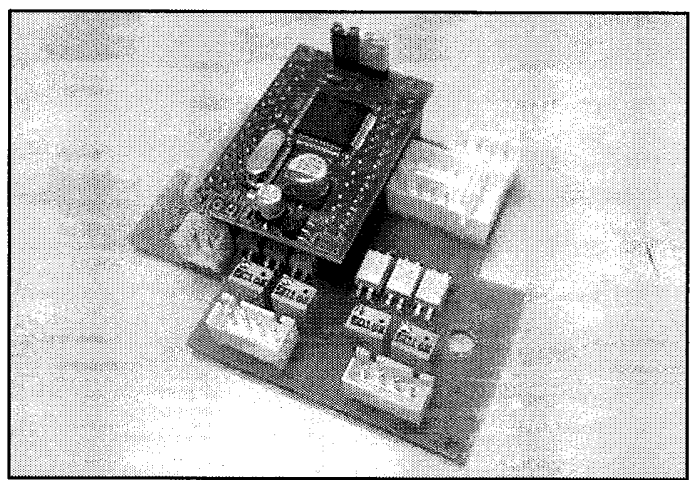

Fig.3 Micro computer module

\section{3 音声制御式}

音声制御式のシステムは，押しボタン式電動車椅子に音声 認識・合成ユニットを追加した構成となっている。

使用者は，図 4 のようにへッドセットを使用し音声命令に より車椅子を操作する。
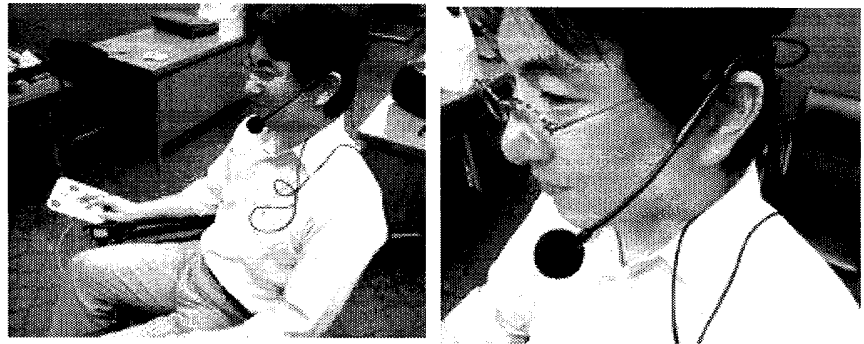

Fig.4 A Headset for a voice control

音声命令は，「まえ」「うしろ」「みぎ」「ひだり」「と まれ」の5つの命令を音声想識・合成ユニットに登録した。

音声制御式の操作方法には，音声命令のみで操作する「A
モード」と音声命令で動作を開始しボタン操作パネルのスト

ップボタンで停止する「Bモード」がある。

追加の使用機材を表 3 に音声認識・合成ユニットを図 5 に 示す.

Table 3 Used equipments of a joystick type

\begin{tabular}{|l|l|}
\hline \multicolumn{1}{|c|}{ Equipment } & \multicolumn{1}{c|}{ Maker and Model } \\
\hline \hline Voice recognize unit & TOSHIBA IT Control systems \\
\hline Headset & Audio-technica AT-810F \\
\hline
\end{tabular}

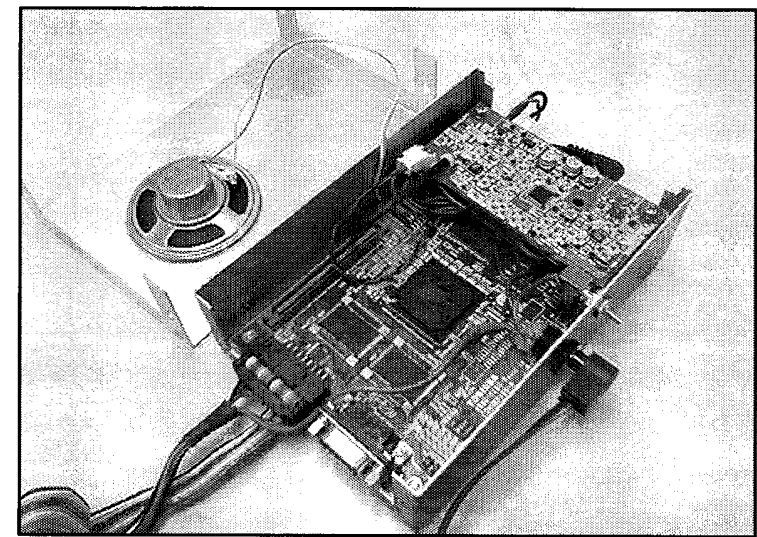

Fig.5 Voice Recognize unit

\section{3. 走行実験}

\section{1 実験条件}

走行実験は，室内での操作を想定した図 6 に示されるコ 一スにより行なった。コース幅の1.2[m]は，JIS 規格の電動車 椅子の最大全長が 1.2[m]であり，電動車椅子がコーナ一部分 で無理なく回転できる広さとして決定した。

被験者には，電動車椅子のそれぞれの操作方法に慣れても らうためにあらかじめコースを試走してもらい，その後の走 行で走行完了時間と，方向転換の回数を測定した.

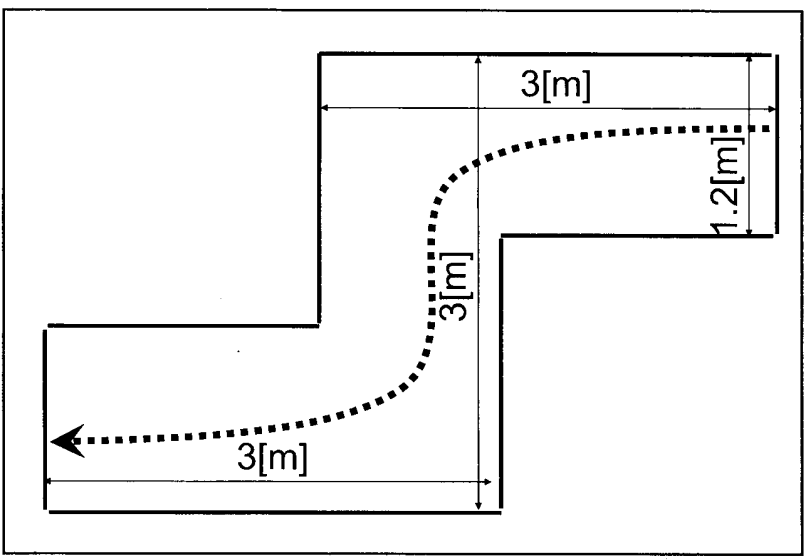

Fig.6 Layout of a testing course

通常のジョイスティック式電動車椅子の走行速度は最高 $4[\mathrm{~km} / \mathrm{h}]$ で, ジョイスティックの操作により操作者が速度を可 変することが可能である。しかし，今回実験を行う他の操作 
万法では，速度を任意に可変する機構がないため，衝突など の安全性を考慮して最高速度を $1[\mathrm{~km} / \mathrm{h}]$ とし，ジョイスティッ ク式も調整して最高速度を同じ速度に変更した。

方向転換の回数は，車椅子が前進から旋回または旋回から 前進に転換した回数を累積した。また，同じ動作でも間に停 止動作がある場合には同様に累積した。

最も少ないと思われる方向転換の回数は「まえ一ひだり一 まえーみぎ一まえ」の 5 回である。

\section{2 実験結果}

走行実験での測定結果を図 7 に示し，測定值の平均を表 4 に示す。

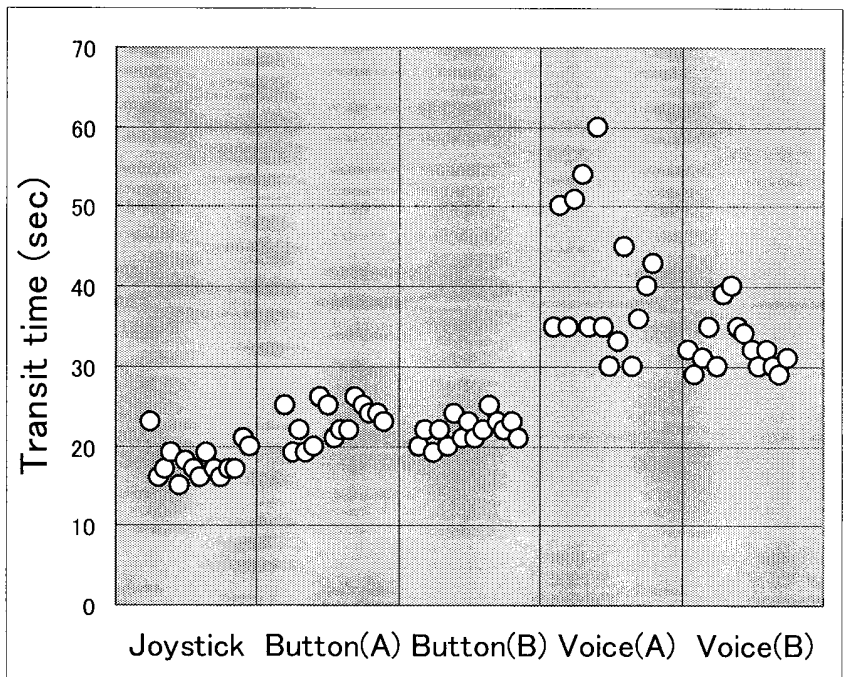

Fig.7 Result of the running test

Table 4 Average Value of the running test

\begin{tabular}{|l|c|c|}
\hline Control Type & $\begin{array}{l}\text { Average time of } \\
\text { Transit time }\end{array}$ & $\begin{array}{l}\text { Average count of } \\
\text { turning counts }\end{array}$ \\
\hline \hline Joystick & $17.9[\mathrm{sec}]$ & 6.7 \\
\hline Push Button(A) & $22.9[\mathrm{sec}]$ & 7.3 \\
\hline Push Button(B) & $21.9[\mathrm{sec}]$ & 7.5 \\
\hline Voice Control(A) & $40.8[\mathrm{sec}]$ & 8.4 \\
\hline Voice Control(B) & $32.6[\mathrm{sec}]$ & 6.0 \\
\hline
\end{tabular}

走行実験の結果，ジョイスティック式が最も短時間に走行 することができた。方向転換の回数も少なかった．

押しボタン式は，ジョイスティック式に比べ走行時間がか
かっている。これは、ジョイスティック式がアナログ的な角 度調整ができるため図 6 の点線のように滑らかに走行するこ とができることに比べ，押しボタン式では「前後左右」の 4 つの方向のみで制御を行なう必要があるために，直線と回転 により方向を制御する必要があるためと思われる.

押しボタン式では「A モード」と「B モード」による結果 の大きな違いはなかった。

音声制御式は「A モード」で，非常に時間がかかり方向転 換の回数も多くなっている。また，図 7 からも走行時間のば らつきが目立っている，方向転換の回数も多いことから，方 向転換に手間取っていることが分かる.

一方「 $\mathrm{B}$ モード」では，時間は他の方式に比べかかってい るが，走行時間のばらつきも「Aモード」に比べ小さく，方 向転換の回数は最も少なくなっている.

今回の実験から操作方法による走行時間のばらつきを式(1) の平方和と, 式（2）の標本標準偏差を用いて調べた。結果を 表 5 に示す。

$$
\begin{aligned}
& s^{2}=\sum\left(x_{i}-\bar{x}\right)^{2} \\
& \hat{\sigma}= \pm \sqrt{\frac{1}{n-1} \sum_{i=1}^{n}\left(x_{i}-\bar{x}\right)^{2}}
\end{aligned}
$$

表 5 の計算結果からも音声制御式の「Aモード」の走行時 間は，他の方式に比べ極端にばらつきが大きいことがわかる.

Table 5 Calculate of Sample standard deviation

\begin{tabular}{|l|c|c|}
\hline Control Type & Square sum & $\begin{array}{l}\text { Sample standard } \\
\text { deviation }\end{array}$ \\
\hline \hline Joystick & 65.7 & 2.17 \\
\hline Push Button(A) & 75.9 & 2.33 \\
\hline Push Button(B) & 35.7 & 1.60 \\
\hline Voice Control(A) & 1206.4 & 9.28 \\
\hline Voice Control(B) & 161.6 & 3.40 \\
\hline
\end{tabular}

\section{4. 実験結果の考察}

電動車椅子の操作方法として一般に使われているジョイス ティック式は，今回の走行実験でも最も短い時間で走行でき, 
方向転換の回数も少なく，操作性がよいことが確認できた。

しかし、ジョイスティックを使用したことがない操作者に は，押しボタン式の方が移動する方向が分かりやすいという 意見もあった，走行時間のばらつきを見てもジョイスティッ ク式と同じ程度ばらつきであり，操作上は問題なく使用でき ると思われる。

押しボタン式の走行時間がジョイスティック式に比べかか っている原因として，前項でも触机たコース上の走行ルート にある。ジョイスティック式が全方向に無制限で方向転換で き，更に速度の加減ができることに対し，今回の実験に使用 した押しボタン式の場合は，直線と回転だけで走行しなけれ ばならないため，回転をしながら前に進むことができない。

そのため, 図 8 の (a)(b)に示される 2 種類の走行ルートが最 もよく用いられ，万向転換の回数は(a)が 5 回，(b)の９回とな る。そのため、ジョイスティック式よりも若干時間がかかる ことと同時に方向転換の回数も多くなっていると考えられる。

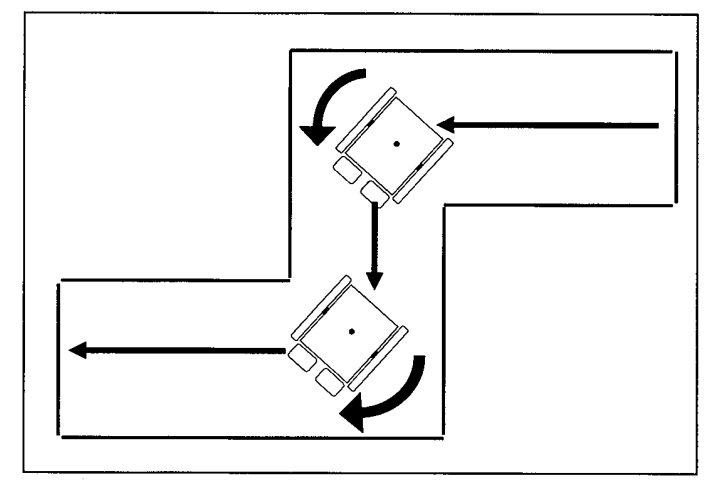

(a) A short line

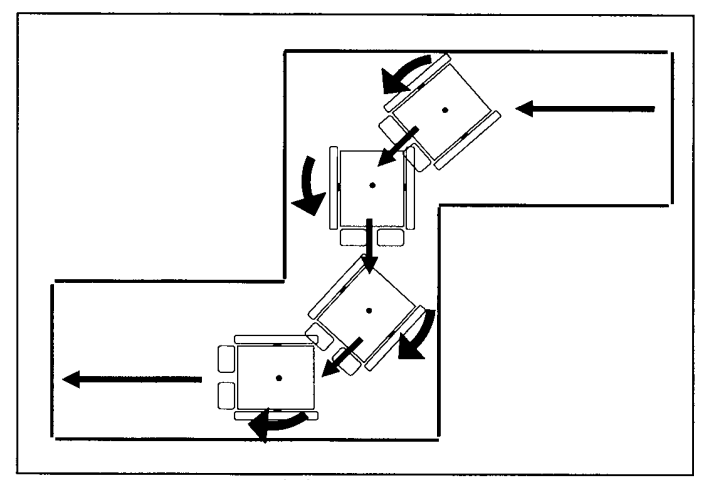

(b) A long line

Fig.8 Trace line using Push-button system

前者 $2 つ 0$ 方式に比べ音声認識式は，多くの問題をかかえ ている、まず，「A モード」の走行時間の平均值は，ジョイ スティック式や押しボタン式の 2 倍以上であり，特に表 5 か らもわかるようにばらつきが大きい。これは，音声命令に費 やす時間が大きく起因していると思われる。

音声命令には，今回の命令語「まえ，みぎ，ひだり，とま れ」の場合, 約 1[sec]かかる. 万向転換ごとにこの時間がか かり，押しボタン式と同じ走行ルートを使用したとすると， 押しボタン式の走行時間に 7[sec]から 8[sec]を加えた值にな
ると予想され，図 7 からも $35[\mathrm{sec}]$ 前後の時間が最も多くなっ ている。

しかし，さらに最大 60[sec]かかる場合もあり，一度操作者 の希望する方向からずれてしまうと，方向修正を行なうため に多くの時間が必要である。実験の様子から「とまれ」とい う音声命令に 1[sec]程度かかることが細かな修正を行なう場 合に問題であることが分かった。この時間は，回転角度で約 30[deg]から 45[deg]であり，音声命令だけではこの角度以下 の細かな制御はむずかしい.

そこで，音声制御式の「B モード」では，「とまれ」の音 声命令の代わりに押しボタン式「Bモード」で使用した

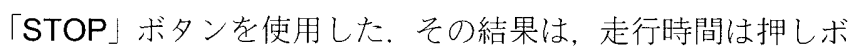
タン式に音声命令に必要な時間を加えた値とほぼ同じとなり, ばらつきも小さくなった，操作者からも，非常に扱いやすく なったという意見が出された。

本来, 音声制御式は，ジョイスティックや押しボタンなど の操作に不慣れな高齢者や，障がいにより他の操作方法が困 難な場合に使用されることが想定され，「STOP」ボタンがし ようできない場合もあるので，操作補助として筆者らが研究 しているRFタグによる位置・方位検出システムとの組み合わ せは，大いに期待できると考えている。

\section{5. まとめ}

本研究の結果を以下にまとめる.

(1) 電動車椅子の操作方法として押しボタン式と音声制 御式を試作した。

(2) ジョイスティック式，押しボタン $(A, B)$ 式，音声制御 $(A, B)$ 式の 5 種類の操作方法を用いて電動車椅子の走行 実験を行い走行時間と方向転換回数を測定した。

(3) ジョイスティック式は, 速度と方向を同時に制御でき るため操作がしやすいことを確認した。

(4) 押しボタン $(A, B)$ 式は，時間的にはジョイスティック 式に及ばないが, 操作性についてはジョイスティック式 と同等であった。

(5) 音声制御(A)式は，他の方法と比較すると操作がむず かしく走行時間がかかりばらつきも多いが，音声制御 (B)式では停止にストップボタンを使用することにより 走行時間・方向転換ともに大きく改善できた。

今後は,さらに多くの被験者により実験を行なうとともに, RF タグなどを用いたシステムと組み合わせ，誰もが使いやす い電動車椅子の操作方法と操作補助について研究する予定あ る.

\section{文 献}

[1] ユニバーサルデザイン研究会編:ユニバーサルデザイン，H本丁 業计版，ISBN4-8190-1506-0

[2]高公，烦原主部：音卢制御の电椅子。 Technical Report of IECE.SSS2003(2003-05)

[3] 橋場参生, 中息康愽：音声操作型電動电㥓子の開発之評体, Technical Report of IEICE.WIT2002-66(2002-12) 